\title{
Protection network in the assistance to children, adolescents and their families in situation of violence
}

\author{
Rede de proteção na assistência às crianças, adolescentes \\ e suas famílias em situação de violência \\ Red de protección en asistencia a niños, adolescentes \\ y sus familias en situación de violencia
}

How to cite this article:

Melo RA, Carlos DM, Freitas LA, Roque EMST, Aragão AS, Ferriani MGC Protection network in the assistance to children, adolescents and their families in situation of violence. Rev Gaúcha Enferm. 2020;41:e20190380. doi: https://doi org/10.1590/1983-1447.2020.20190380
- Universidade Federal do Vale do São Francisco (UNIVASF), Departamento de Saúde, Colegiado de Enfermagem. Petrolina, Pernambuco, Brasil.

- Universidade Federal de São Carlos (UFSCAR), Centro de Ciências Biológicas e da Saúde, Departamento de Enfermagem. São Carlos, São Paulo, Brasil.

Pesquisador autônomo. Uberlândia, Minas Gerais, Brasil.

${ }^{d}$ Universidade de Ribeirão Preto (UNAERP). Departamento de Pós-Graduação em Serviço Social. Mestrado profissional. Ribeirão Preto, São Paulo, Brasil.

e Universidade Federal do Triângulo Mineiro (UFTM) Departamento de Saúde Coletiva, Núcleo de Pesquisa em Saúde e Sociedade (NUPESS). Uberaba, Minas Gerais, Brasil.

' Universidade de São Paulo (USP), Escola de Enfermagem de Ribeirão Preto, Departamento de Enfermagem Materno-Infantil e Saúde Pública. Ribeirão Preto, São Paulo, Brasil.

\section{ABSTRACT}

Objective: To understand the performance of the protection network for children, adolescents, and their families in situations of intrafamily violence, from the perspective of professionals of the Specialized Reference Center for Social Assistance.

Method: A qualitative study conducted with five Specialized Reference Center for Social Assistance professionals in a Pernambucan municipality. Data collection was conducted from October 2017 to January 2018 by means of a semi-structured interview, with data analyzed by the thematic content technique.

Results: The professionals know how the protection network works, but they see the deductive logic of the team; the lack of material resources; the difficulty of articulation; and the logistics of care flow as limiting factors for maintaining effective care.

Conclusion: The performance of the protection network must be able to ensure the rights of children, adolescents, and their families in situations of violence, through articulated and integrated care, aiming at changing attitudes and breaking the cycle of violence. Keywords: Social support. Protection. Violence. Child. Adolescent.

\section{RESUMO}

Objetivo: Compreender a atuação da rede de proteção às crianças, adolescentes e suas famílias em situação de violência intrafamiliar, na ótica dos profissionais do Centro de Referência Especializado da Assistência Social.

Método: Estudo qualitativo e descritivo, realizado com cinco profissionais do serviço. A coleta dos dados foi realizada entre outubro de 2017 a janeiro de 2018, por entrevista semiestruturada, sendo os dados analisados por Análise de Conteúdo Temática.

Resultados: Os profissionais conhecem o funcionamento da rede de proteção, no entanto visualizam a lógica dedutiva da equipe; a falta de recursos materiais; a dificuldade de articulação e a logística de fluxo de atendimento como fatores limitantes para uma assistência efetiva.

Conclusão: A atuação da rede de proteção deve ser capaz de assegurar os direitos de crianças, adolescentes e suas famílias em situação de violência, através do atendimento articulado e integrado, visando a mudança de atitudes e quebra do ciclo da violência. Palavras-chave: Apoio social. Proteção. Violência. Criança. Adolescente.

\section{RESUMEN}

Objetivo: Comprender el desempeño de la red de protección para niños, adolescentes y sus familias en situaciones de violencia intrafamiliar, desde la perspectiva de los profesionales del Centro Especializado de Referencia de Asistencia Social.

Método: Estudio cualitativo realizado con cinco profesionales del Centro de Referencia Especializado para Asistencia Social en un municipio de Pernambuco. La recopilación de datos se realizó de octubre de 2017 a enero de 2018 por medio de entrevistas semiestructuradas, y los datos se analizaron con la técnica de contenido temático.

Resultados: Los profesionales conocen el funcionamiento de la red de seguridad; sin embargo, ven a la lógica deductiva del equipo, a la falta de recursos materiales, a la dificultad de articulación y a la logística del flujo de atención como factores limitantes para mantener una atención efectiva.

Conclusión: El funcionamiento de la red de seguridad debe ser capaz de garantizar los derechos de los niños, adolescentes y sus familias en situaciones de violencia, a través de una atención articulada e integrada, con el objetivo de cambiar las actitudes e interrumpir el ciclo de la violencia.

Palabras clave: Apoyo social. Protección. Violencia. Niño. Adolescente. 


\section{口INTRODUCTION}

Children and adolescents are beings who have existential peculiarities in relation to their development, and their rights are guaranteed through the Brazilian Statute of Children and Adolescents (Estatuto da Criança e do Adolescente, ECA)(1). Since its inception, the ECA has been premised on ensuring full protection for these individuals and, since then, has instituted and ensured substantial changes in the assistance policies targeted to children and adolescents, especially those victims of violence( ${ }^{(2)}$.

Despite all the efforts, children and adolescents are part of the human groups most vulnerable to various forms of daily violence, especially that which occurs within the family, highlighting the need for this problem to be seen as relevant from a social and scientific point of view. In this context, it is emphasized that the development of today's society warns about the growing number of cases of children and adolescents in situations of violence, especially within the family, reasserting this as a serious international public health problem ${ }^{(3)}$.

The World Health Organization (WHO) defines intrafamily violence against children and adolescents as acts or omissions practiced by parents, relatives or guardians, either of a psychological, physical and/or sexual nature, with the potential to cause pain and suffering to the individuals affected ${ }^{(4)}$. The occurrence of violence in childhood and adolescence has negative consequences ranging from learning disabilities, feelings of anger, sadness and depression, self-destructive behaviors, and even suicidal thoughts ${ }^{(5-6)}$.

It is reiterated that the early and recurrent experience of situations of daily violence, especially involving children and adolescents, leads to a negative process of social adaptation in adulthood, and enhances the internalization of anxiety symptoms, depressive disorders, low self-esteem, and other late psychological problems. In addition, there is greater likelihood of developing conflicts in intimate relationships in adulthood, having difficulty dealing with their own feelings and a tendency to reproduce the violence experienced, especially with their children and other family members, favoring the exacerbation of the violent cycle ${ }^{(7)}$.

The protection network for children, adolescents, and their families in situations of violence is conceptualized as a space for the formation of partnerships, cooperation, and articulations of institutional subjects, functioning as an effective mechanism for the interruption of violence, favoring a broader view of situations, and allowing for the planning of integrated actions. The good functioning of the network favors the sharing of responsibilities on the cases, allowing each professional and sector and/or service to act within their profile ${ }^{(8-10)}$.

The composition of the protection network involves several bodies, such as social and psychological assistance services like the Social Assistance Reference Centers (Centros de Referência da Assistência Social, CRAS) and the Specialized Social Assistance Reference Centers (Centros de Referência Especializados da Assistência Social, CREAS); the Councils of Rights; the Guardian Councils; the public prosecutor's office; and the childhood and youth courts, as well as other institutions that provide services such as schools, health units, and welcoming units, among other support networks, such as police stations and organized civil society ${ }^{(11)}$.

The CREAS is defined as an organ to assist in and confront various types of violence against children and adolescents, which aims at the protection and full guarantee of the rights of the children and their families against violation of rights, being an articulator of social protection of medium complexity, and should be composed of a multidisciplinary team of psychologist, social worker, lawyer, and social educator ${ }^{(10)}$.

The Federal Constitution of 1988 and the ECA provide that the family, society, and the State have a duty to ensure that all rights of children and adolescents, with regard to life, food, education, dignity and respect, are guaranteed, not allowing any kind of exposure to any form of negligence, discrimination, and violence ${ }^{(1,12)}$. In view of this, the professionals who work in the protection network services have specific responsibilities, and must also be committed to the formulation of intervention strategies that involve the victims and their families in preventing vulnerable situations ${ }^{(2)}$.

Thus, considering the information listed, this research was justified by the fact that violence in the family context of children and adolescents is a strong negative predictor in the growth and development of these individuals and interferes in family relationships, as well as by the need to have a discussion regarding the performance of the professionals and of the services that make up the protection network against intrafamily violence.

Given the above, this study started from the following questions: How do the CREAS professionals, involved in assisting children, adolescents, and their families in situations of intrafamily violence, perceive networking? How does the network assist adolescents in situations of violence at the CREAS, and how does it deal with the difficulties in operating this assistance? Thus, this study aimed to understand the performance of the protection network for children, adolescents, and their families in situations of intrafamily violence, from the perspective of the professionals who work in the Specialized Reference Center for Social Assistance. 


\section{METHOD}

This is a descriptive and exploratory study with a qualitative approach. The research was carried out with professionals working at the CREAS in an inland city of the state of Pernambuco. This municipality has an estimated population of 343,219 and is 710 kilometers from the capital, Recife. The municipality is part of the Pernambuco/Bahia interstate network (PEBA network), acting as a reference in health and social assistance for the entire macro-region of Vale do São Francisco ${ }^{(13)}$. The health care network consists of 365 institutions, 86 of which belong to the municipal public administration, including the municipal CREAS.

Five professionals were interviewed, them being a psychologist, two social workers, a lawyer, a social educator, and an administrative assistant. They were recruited directly in the CREAS, and the initial objective of the study was explained to them so that, after clarification, they signed the Free and Informed Consent Term, accepting to participate in the research. The criteria for inclusion of the participants were the following: having been working professionally in the CREAS for at least six months; having had some kind of professional contact or provided some care to children, adolescents, and families in situations of violence. The exclusion criterion was being on vacation or leave during the data collection period.

Data was collected between October 2017 and January 2018 by means of semi-structured interviews conducted individually, in a reserved room at the professionals' own workplace. It is highlighted that, during the data collection period, five professionals worked in the CREAS, and all agreed to participate in the study. The interviews were guided by a script of guiding questions that included the knowledge of the professionals regarding the assistance of the protection network to children, adolescents, and their families in situations of intrafamily violence. They were carried out with the aid of a portable recorder, each interview lasting a mean of 25 minutes. To preserve anonymity, the professionals were identified using the Pf code and numbers, corresponding to the order in which the interviews were conducted (Pf1, Pf2 ... Pf5).

Data was analyzed based on the concept of network performance ${ }^{(11)}$. The thematic analysis technique was targeted by means of the following steps: (I) Familiarization with the data: after transcribing the interviews and groups, exhaustive readings and re-readings of the data set were carried out; (II) Coding: it was sought to reference and code the relevant information according to the research questions, by means of codes that captured the semantic and conceptual reading of the data; the codes were grouped with the relevant data extracted from the information set; (III) Theme search: a theme is a coherent and meaningful standard in the data relevant to the answer to the research question; the codes from the previous phase were grouped in these themes; (IV) Theme review: it was checked whether the themes worked according to the extracted data codes and their relation to the general data set; $(V)$ Definition and naming of the themes: a detailed analysis of each theme was conducted, identifying the essence of each one; (VI) Final writing: an integral element of the thematic analysis, which involves the joint weaving of the analytical narrative, as well as its contextualization with relevant literature of the area, legal provisions, and articulation with the theoretical concepts. To ensure greater validity and reliability of the data, the following strategies recommended by literature instruments were performed: (i) member-checking: feedback of the data to the participants to "check" the coherence of the content; (ii) peer analysis: the construction of referential tables and categories (Chart 1) was carried out by two researchers in the study, and validated by a third when necessary; (iii) use of the field diary, ensuring greater transparency of the entire research process ${ }^{(14)}$.

This study was conducted in accordance with the ethical standards required by Resolutions 466/2012 and 510/2016, being approved by the Research Ethics Committee of the Federal University of Vale do São Francisco, under opinion No.2,677,484 and CAAE No. 86721018.2. 0000.5196.

\section{RESULTS AND DISCUSSION}

The interviewed professionals had a mean age of 31 years old, three had children, and all were married. One had a specialization in Behavioral Psychology, three were graduating in related fields, and one of them had no specialization. Two were linked to other services, however outside the context of the protection network.

After exhaustive reading of the reports found and the codification, three final themes were extracted, which will be listed and discussed below.

\section{Understanding of the protection network and its flows}

Considering that what is meant by a network does not always involve its initial conception, since an understanding of articulated work and organizational strategy is required, it was observed that the professionals showed an adequate understanding regarding the central objective of the protection network, as well as the purpose of the services that 


\begin{tabular}{|c|c|c|}
\hline Initial Codes & Intermediate codes & Final themes \\
\hline Help services & \multirow{4}{*}{$\begin{array}{l}\text {-Violence } X \text { protection } \\
\text {-Interrupting the cycle } \\
\text {-Protection network }\end{array}$} & \multirow{4}{*}{$\begin{array}{l}\text { Understanding of the protection } \\
\text { network and its flows }\end{array}$} \\
\hline Defense & & \\
\hline Referral & & \\
\hline Avoiding new instances of violence & & \\
\hline Demands & \multirow{3}{*}{$\begin{array}{l}\text {-Challenges faced } \\
\text {-Multi-professional team }\end{array}$} & \multirow{3}{*}{$\begin{array}{l}\text { The CREAS team in the protection } \\
\text { of children, adolescents, and their } \\
\text { families in situations of violence }\end{array}$} \\
\hline Team shortage & & \\
\hline Social and psychological support & & \\
\hline Limits & \multirow{3}{*}{$\begin{array}{l}\text {-Team turnover X breakdown of care } \\
\text {-Standardization of care }\end{array}$} & \multirow{3}{*}{$\begin{array}{l}\text { Limitations of the performance } \\
\text { of the CREAS in cases of } \\
\text { intrafamily violence }\end{array}$} \\
\hline Limited care & & \\
\hline Lack of resources & & \\
\hline
\end{tabular}

Chart 1 - Referential charts and final categories Source: Research data

compose it. Even with this understanding, they showed flaws in the functioning of the service in which they work [CREAS]:

[...] It is the service that helps to implement measures that protect children and adolescents against cases of violence... indeed, it protects everyone. [...] We can refer the individuals to other spheres and maintain protection. (Pf1) I see how the system that favors the non-occurrence of new cases of violence in these boys [...] where the team can be acting to protect and prevent new violence from happening, especially for children who are more fragile than teenagers and the other groups. (Pf3)

[...] It is a tangle of places and services that comes to prevent violence from happening or that there is no revictimization [...]. But, I see that many of these services do not work as they should and end up revitalizing these little creatures even more... like here the very CREAS that almost never works as it should. (Pf4)

It is a network that has several protection services against violence, but that does not always work correctly, as is the case with our service, which sometimes does not even have a coordinator and is almost always absent from the team. (Pf5)
Despite showing an understanding of the logistics of the protection network and its importance in interrupting the cycle of violence against children and adolescents, it was observed that the professionals identified and recognized that the service where they work still fails to provide protection to this population. This aspect was related to the lack of structure and to the discontinuity of the care provided, evidenced by the reduction of the team, which directly impacts on the quality of the social assistance service proposed to the assisted individuals.

From this perspective, it is worth noting that the protection network is configured as a set of organizations, institutions, and individuals whose objective is to promote the interruption of the cycle of violence through sharing causes and projects, in a democratic and supportive way, with connectivity and division of responsibilities and competences. This perspective is based on a concept of collective and articulated work, in the search for the effectiveness of its actions and services as recommended by the $E C A^{(10,15)}$. When considering the comprehensive protection of children and adolescents, the ECA establishes that care must be organized through supplementary social assistance policies and programs for all who need them, as well as through prevention and psychosocial care 
services for people in situations of violence, oppression, and mistreatment ${ }^{(1)}$.

The legitimized logic of a truly articulated network must start from an intense and continuous movement, which manages to integrate the different segments and services that are part of that network. However, it is recognized that, for this reality to materialize, there is a need for constant dialog between the professionals and the various sectors and services; for permanent education of all those involved in this process; and for a more intense search of partnerships that can incorporate this work logistics, in order to allow for the maintenance of the functioning segments that make up this network ${ }^{(10)}$. From this perspective, the professionals, even showing some understanding of what constitutes a protection network, were not able to report which organs and services make up this network, nor the referral and counter-referral flows that can be effective within this process of protecting children and adolescents in situations of violence.

So... \{pause\} ... the services and flow allowed I do not know if to say all, all indeed, but I know that there are the police stations, the Guardian Council, the CRAS... at least that's where we receive the most cases... from what I remember are more those. (Pf1)

Ah, there are several from where we receive, the \{Guardian\} Council, the Child Court, the Children's Hospital, the police, even the Capsl, and we send them back too. (Pf3)

The flow must involve protection in all the spheres. [...] So it could be the hospitals; the police stations; the Guardian Council, which always sends us; the Children and Youth Court, even the schools. (Pf5)

Some important services and flows that make up the protection network have not been mentioned, showing little knowledge of the referrals that can be offered to individuals in situations of violence, especially children and adolescents. The network provides child and youth protection, reconnecting individuals, services, spaces, and opportunities for the integral development of children and adolescents by introducing new values, skills, and processes in the social work in the face of a complex reality. This action allows for the integration of skills and interventions in order to prevent and/or interrupt the cycle of violence. For this action to be effective, an adequate understanding of the network by parts of the actors that make up the services is required ${ }^{(2)}$. The failure in the functioning of the protection network, especially with regard to specialized care, directly interferes in guaranteeing full protection for children and adolescents ${ }^{(16)}$.

The lack of knowledge of the multi-professional team about the articulation that should exist between the organs and services of the protection network raises the question about the effectiveness of the services performed in the CREAS, considering that the amplitude of the attributions and their work proposal within the context of these services should be qualified. The professional who works in these spheres of the network and presents limited knowledge puts quality of care at risk in their area of activity and, consequently, in the other services that make up the network ${ }^{(15)}$.

\section{The CREAS team in the protection of children, adolescents, and their families in situations of violence}

The performance of a complete multi-professional team, articulated and prepared to act in the fight to combat violence against children, adolescents, and their families has great social relevance, as it promotes reflection on an important issue for the advancement of knowledge within the area of performance of each team member and brings positive responses to the demands faced ${ }^{(16)}$.

In this perspective, considering the statements of the interviewees, it was observed that the performance of the CREAS team in interrupting the cycle of violence against children, adolescents, and their families was considered satisfactory, even though there was a deficit in the performance of the service team:

Our team, although not big enough, is very solid and, as I see it, it manages to give a satisfactory answer to the existing demands. (Pf3)

We do what we can to prevent this child and adolescent from suffering violence again or even having any sequelae. So, we give all support from the social, psychological, and legal points of view. (Pf4)

It is observed in the statements that the CREAS professionals perform comprehensively and interdisciplinarily, even with few actors. However, it is highlighted that the actions of professionals in an isolated and disjointed way are not enough to respond to the demands of prevention and coping with situations of violence to which children, adolescents, and their families are vulnerable, requiring greater integration of both the existing services and the professionals qualified to promote this welcoming ${ }^{(17)}$.

According to the ECA, the CREAS centers are services responsible for providing specialized care to children and adolescents in situations of violence, through the performance of a multi-professional team. These services are part of the Unified Social Assistance System, and act in the articulation of social protection of medium complexity, through 
specialized and continuous support to individuals and families whose rights are violated, acting directly in the promotion of guidelines that can serve as a subsidy for preventing and addressing existing violence ${ }^{(10)}$.

The CREAS, as an important service that makes up the protection network, has the potential to encompass and articulate the various professionals and local and regional sectors, with the perspective of favoring comprehensive care in situations of violence, as well as developing a multidisciplinary view, with inter-sectoral actions that improve the living conditions of the victims, contributing to the elaboration of public policies that make it possible to guarantee the constitutional rights of the vulnerable populations ${ }^{(10)}$.

Another point evidenced by the statements was the fact that the interviewees asserted that there was difficulty working with an incomplete team, in most cases composed only of two or three professionals in each category, thus impairing the referral of the existing demands:

[...] We do what we can, we try to give answers to the victims and their families as well, but it is not always easy because we are always working at the limit of our possibilities due to lack of professionals in the multi-team. (Pf2) Here the team is always not big enough [...]. There is lack of psychologists and then, how do we refer those who need psychological support? I'm glad we have some interns who help sometimes. And a social worker is also always needed to be able to help in handling the cases. (Pf4)

We do our best, but we know that the necessary care has to rely on the performance of all the multi-professional team, otherwise we cannot help that person who is in violence [...]. (Pf5)

When seeking to identify the perspective of networking, highlighting the importance of a complete multidisciplinary team and with a minimum number per sector/service, it is understood that it involves a potential mechanism for interrupting the cycle of violence, since it favors an expanded view of the situations, without overload, allowing for integrated actions to be planned and for the sharing of responsibilities in each case $e^{(9)}$. However, for this to materialize, it is necessary that the protection network is built based on collective work, with joint and shared actions, in the form of a "social web", a mesh of multiple wires and connections, therefore being a strategic alliance between social actors (people), with actions based on professionalism, attributions, and competencies of each agent, where professional qualification/training can be decisive in this entire process ${ }^{(2)}$.

\section{Limitations of the performance of the CREAS in cases of intrafamily violence}

When asked about the difficulties encountered in referring the cases of violence in the reference service, it was identified that the performance is limited in many moments, considering the absence of a regulation that directs and standardizes assistance; the lack of an adequate flow of demands; and the inconsistency in service calls:

I see as a limitation this issue of today working with a fixed team, and tomorrow already be broken the contract with some members of the team... [...] Then it breaks the care in the middle. Not to mention the lack of some resources and the lack of coordination with other services. (Pf1)

There are times when there is coordination here and then there is no more. Then another, and another, and so on. This limits us a lot because it prevents us from maintaining a standardization of care. (Pf2)

Look, here is the problem of lack of some resources that allow us to work, even a car to visit. But, we always try to resolve with our contacts. Another problem is this eternal shortage in the team [...] You can't develop a good job like that. That is very limiting! (Pf3)

Coping with intrafamily violence has been accompanied by many challenges, showing that protection services constantly need to review the assisted cases and the dynamics of the flow of care, as well as the structural problems experienced in the sectors of activity. This movement allows us to think of effective and efficient alternatives that are able to address the problem in an articulated way and allow overcoming fragmented or overlapping practices in the relationship with the assisted individuals ${ }^{(16)}$.

The inexistence or even non-adherence to an articulated flow of care, as reported by the professionals interviewed, leads to the maintenance of an occasional and non-systematic flow, corroborating the reality brought by other studies, which showed problems related to lack of knowledge or to discontinuity in this dynamic of care, directing some professionals to act in an isolated and disjointed way, and often using personal influences outside the limits of the protection network to succeed in following up the cases ${ }^{(17-18)}$.

Networking presupposes an interdisciplinary view, considering that the effectiveness of the actions depends on the integration of the professionals and the services, as well as on the maintenance of sectors with a complete multidisciplinary team and adequate physical and material structure. 
There is also a need to invest in the interlocution of their management, intra- and inter-sectoral, in order to ensure quality care for the victims of violence, since fragilities in these variables weaken and atomize the existing institutions ${ }^{(2,18)}$.

In this perspective, the importance of the search for partnerships that make it possible to carry out inter-sectoral actions is emphasized, with a view to making complementary and cooperation covenants feasible among social actors, organizations, projects, and services, which depend, above all, on individual wills and interests in favor of the collective. Thus, the implementation of inter-sectoral and multi-professional actions tends to optimize spaces, services, and skills, being an essential condition for children, adolescents, and their families to be fully cared for, as provided for in the ECA, and to be removed from the situations of vulnerability to which they are exposed ${ }^{(19)}$.

\section{FINAL CONSIDERATIONS}

The results of the present study showed how the CREAS professionals work in a network with regard to the care provided to children, adolescents, and their families in situations of intrafamily violence. The participants demonstrated a limited perception of the performance of the protection network, within the perspective of demand for the services in which they operate, and were unable to fully identify the services and referral and counter-referral flows that are part of this protection network.

It was also observed that the great difficulties in relation to the number of members of the multidisciplinary team, and the low articulation and maintenance of the flow of care in partnership with the other services that make up the protection network, are determinant for the compromise of the quality of the interventions performed, impacting on the effectiveness and efficiency of the care provided to the assisted individuals.

The limitations of the study involved the fact that the multi-professional team was not complete at the time of the research, and that there was high turnover of coordinators, which made it difficult for them to adhere to the research, with the consequent delay in granting the letter of consent for the beginning of data collection. Another limitation was the manager's impediment to conduct the focus groups, a methodology initially planned to complement the considerations brought up in the semi-structured interviews.

It is understood that the work performed by the multi-professional team of the services that make up the protection network, in any sphere of activity, must have a minimum of material structure and human resources so that the work can be carried out properly and the goal is attained of guaranteeing rights, minimizing the various existing vulnerabilities and preventing the occurrence of new forms of violence, as well as promoting coping and empowerment in the individuals.

Therefore, it is understood that, for the actions of the multi-professional team to show positive responses, it is necessary that the professionals have quality professional training, and that the managers give these professionals the opportunity to participate in permanent education actions, so that these individuals feel able to develop excellence in their work, viewing each situation in a peculiar way and understanding that each individual and family is in a situation of vulnerability with different referral needs.

\section{REFERENCES}

1. Presidência da República (BR). Lei no 8.069, de 13 de julho de 1990. Dispõe sobre o Estatuto da Criança e do Adolescente e dá outras providências. Brasília, DF; 1990.

2. Faraj SP, Siqueira AC, Arpini DM. Rede de proteção: 0 olhar de profissionais do sistema de garantia de direitos. Temas Psicol. 2016;24(2):727-41. doi: https:// doi.org/10.9788/TP2016.2-18

3. Morais RLGL, Sales ZN, Rodrigues VP, Oliveira JS. Actions of protection for children and teenagers in situations of violence. J Res Fundam Care Online 2016;8(2):4472-86. doi: https://doi.org/10.9789/2175-5361.2016.v8i2.4472 $-4486$

4. Krug EG, Dahlberg LL, Mercy JA, Zwi AB, Lozano R, editors. Word report on violence and health. Geneva: WHO; 2002 [cited 2016 Aug 05]. Available from: https://apps.who.int/iris/bitstream/handle/10665/42495/9241545615_eng. pdf;jsessionid $=$ C8474D24C0837972E7FB8C8BB5453D42? sequence $=1$

5. Conceição MIG, Macedo EOS. Atendimento psicossocial a crianças e adolescentes em situação de violência: o psicólogo e a rede de atenção. Pesqui Prát Psicossociais. 2017 [cited 2019 0ct 27];12(1):129-46. Available from: http://pepsic.bvsalud.org/pdf/ppp/v12n1/10.pdf

6. Schek G, Silva MRS, Lacharité C, Bueno MEN. Professionals and interfamily violence against children and adolescents: in between legal and conceptual precepts. Rev Esc Enferm USP. 2016;50(5):780-5. doi: https://doi.org/10.1590/ s0080-623420160000600010

7. Moore SE, Scottb JG, Ferrari AJ, Mills R, Dunne MP, Erskine HE, et al. Burden attributable to child maltreatment in Australia. Child Abuse Negl. 2015;48:20820. doi: https://doi.org/10.1016/j.chiabu.2015.05.006

8. Pinto LSS, Oliveira IMP, Pinto ESS, Leite CBC, Melo NA, Deus MCBR. Women's protection public policies: evaluation of health care for victims of sexual violence. Ciênc Saúde Coletiva. 2017;22(5):1501-8. doi: https://doi.org/10.1590/141381232017225.33272016

9. Garbin CAS, Bordin D, Fadel CB, Garbin AJl, Saliba NA. A ruptura social infantojuvenil e sua inferência nas representações de conselheiros tutelares. Trab Educ Saúde. 2017 [cited 2019 0ct 27];15(1):269-82. Available from: https://doi. org/10.1590/1981-7746-sol00042

10. Carlos DM, Pádua EMMD, Fernandes MID, Leitão MNC, Ferriani MGC. Domestic violence against children and adolescents: social support network perspectives. Rev Gaúcha Enferm. 2016;37(spe):e72859. doi: https://doi.org/10.1590/19831447.2016.esp.72859 
11. Ministério da Saúde (BR). Secretaria de Vigilância em Saúde. Departamento de Análise de Situação de Saúde. Linha de cuidado para a atenção integral à saúde de crianças, adolescentes e suas famílias em situação de violências. Brasília: Ministério da Saúde; 2010 [cited 2018 Nov 15]. Available from: http://bvsms. saude.gov.br/bvs/publicacoes/linha_cuidado_criancas_familias_violencias.pdf

12. Constituição da República Federativa do Brasil. Brasília, DF: Senado Federal; 1988.

13. Instituto Brasileiro de Geografia e Estatística [Internet]. Rio de Janeiro: IBGE; c2017 [cited 2018 Nov 15]. Brasil/Pernambuco/Petrolina; [aprox. 1 tela]. Available from: http://www.cidades.ibge.gov.br/xtras/perfil.php?lang=\&cod mun $=261110 \&$ search $=\|$ infogr\%E1ficos:-informa\%E7\%F5es-completas

14. Clarke V, Braun V. Teaching thematic analysis: overcoming challenges and developing strategies for effective learning. The Psychologist. 2013 [cited 2018 Dec 03];26(2):120-3. Available from: http://eprints.uwe.ac.uk/21155

15. Deslandes SF, Campos DS. Guardianship Councilors'views on the effectiveness of the existing network in providing full protection to children and teenagers in situations of sexual violence. Ciênc Saúde Coletiva. 2015;20(7):2173-82. doi: https://doi.org/10.1590/1413-81232015207.13812014
16. Leite JT, Beserra MA, Scatena L, Silva LMP, Ferriani MGC. Coping with domestic violence against children and adolescents from the perspective of primary care nurses. Rev Gaúcha Enferm. 2016;37(2):e55796. doi: https://doi. org/10.1590/1983-1447.2016.02.55796

17. Schek G, Silva MRS. Feelings experienced by professionals who work in services to protect children and adolescents victims of intrafamily violence and its effects in daily practice. J Res Fundam Care Online. 2018;10(3):764-9. doi: https://doi. org/10.9789/2175-5361.rpcfo.v10.6196

18. Veloso MMX, Magalhães CMC, Cabral IR. Identificação e notificação de violência contra crianças e adolescentes: limites e possibilidades de atuação de profissionais de saúde. Mudanças Psicol Saúde. 2017;25(1):1-8. doi: https:// doi.org/10.15603/2176-1019/mud.v25n1p1-8

19. Sousa MCL. Rede de proteção social frente à violência contra crianças e adolescentes: um estudo a partir do Conselho Tutelar III de Ananindeua/PA [dissertação]. Belém (PA): Universidade Federal do Pará; 2018 [cited 2019 0ct 10]. Available from: http://repositorio.ufpa.br/jspui/bitstream/2011/10894/1/ Dissertacao_RedeProtecaoSocial.pdf

\section{- Corresponding author:}

Rosana Alves de Melo

E-mail: rosananurse@hotmail.com

\section{Associate editor:}




\section{Erratum of article:}

Melo RA, Roque EMST, Freitas LA, Carlos DM, Aragão AS, Ferriani MGC. Protection network in the assistance to children, adolescents and their families in situation of violence. Rev Gaúcha Enferm. 2020;41:e20190380. doi: https://doi.org/10.1590/1983-1447.2020.20190380

\section{On page 1, Authors and Affiliations, where it reads:}

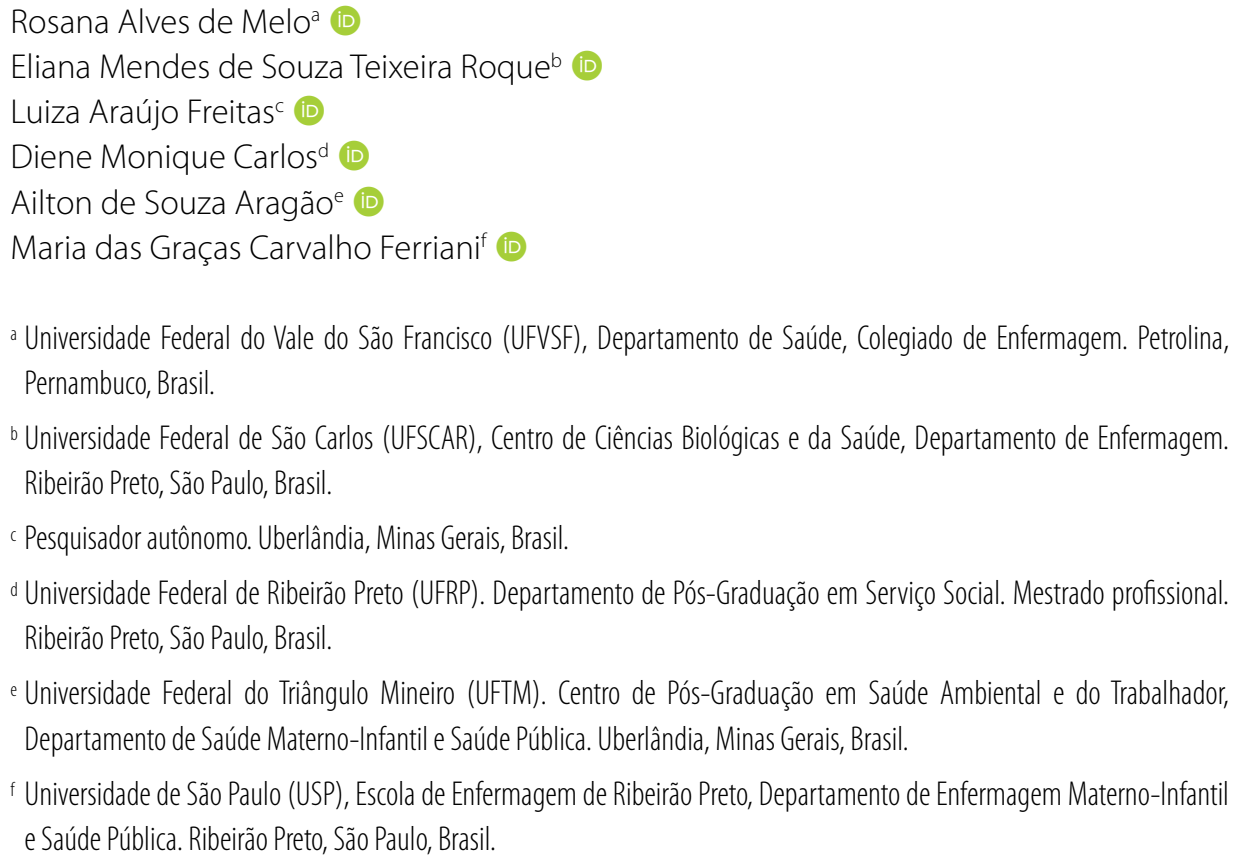

\section{should read:}

Rosana Alves de Meloa

Diene Monique Carlos ${ }^{\mathrm{b}}$ (ib)

Luiza Araújo Freitas ${ }^{c}$

Eliana Mendes de Souza Teixeira Roque ${ }^{d}$

Ailton de Souza Aragão (it)

Maria das Graças Carvalho Ferrianif

a Universidade Federal do Vale do São Francisco (UNIVASF), Departamento de Saúde, Colegiado de Enfermagem. Petrolina, Pernambuco, Brasil.

b Universidade Federal de São Carlos (UFSCAR), Centro de Ciências Biológicas e da Saúde, Departamento de Enfermagem. São Carlos, São Paulo, Brasil.

c Pesquisador autônomo. Uberlândia, Minas Gerais, Brasil.

d Universidade de Ribeirão Preto (UNAERP). Departamento de Pós-Graduação em Serviço Social. Mestrado profissional. Ribeirão Preto, São Paulo, Brasil.

e Universidade Federal do Triângulo Mineiro (UFTM). Departamento de Saúde Coletiva, Núcleo de Pesquisa em Saúde e Sociedade (NUPESS). Uberaba, Minas Gerais, Brasil.

f Universidade de São Paulo (USP), Escola de Enfermagem de Ribeirão Preto, Departamento de Enfermagem Materno-Infantil e Saúde Pública. Ribeirão Preto, São Paulo, Brasil. 